Annals of Warsaw University of Life Sciences - SGGW

Land Reclamation No 43 (2), 2011: 207-216

(Ann. Warsaw Univ. of Life Sci. - SGGW, Land Reclam. 43 (2), 2011)

\title{
A stress history and strain dependent stiffness of overconsolidated cohesive soil
}

\author{
MIROSŁAW J. LIPIŃSKI, MAŁGORZATA K. WDOWSKA \\ Faculty of Civil and Environmental Engineering, Warsaw University of Life Sciences - SGGW
}

\begin{abstract}
A stress history and strain dependent stiffness of overconsolidated cohesive soil. In the last three decades an interest has grown in prediction of soil stiffness. This is mainly due to enlightened nonlinearity of constitutive characteristic in small and intermediate range of strain. In the last decade this interest has been extended on natural undisturbed soil. The paper undertakes this subject with an attention focused on Quaternary heavy overconsoldated stiff sandy clay. Series of triaxial tests on reconstituted and natural material were carried out which provided data for setting up formula for calculation Young's modulus in a wide range of strain $10^{-2} \div 1.0 \%$, representative for working ranges in engineering applications. Stress history, in the form of yielding stress, is also accounted for.
\end{abstract}

Key words: undisturbed heavy overconsolidated sandy clay, normalized Young's modulus, stress history, strain range, triaxial tests.

\section{INTRODUCTION}

Stress strain characteristics are key feature of soil when dealing with every day geotechnical engineering practice as well in case of more cognitive approach to nature of soil behavior under imposed loading. It certainly concerns both fundamental kind of problems associated with limit equilibrium states and serviceability limit states. These categories use shear strength and stiffness of soil as a key geotechnical characteristics. Usually, in geotechnical practice the major limitation in the design is rather associated with serviceability limit state which is controlled by stiffness parameters, among which Young's modulus is the most often used. Unfortunately, quantitative evaluation of its characteristic value must account for many variables contributing to the soil stiffness. One of the most vital variable is a stress level with emphasize put on a stress history. Unfortunately this issue is poorly understood, since existing empirical correlations refer to a particular soil with known mechanical preconsolidation stress. Such situation, although interesting with respect to a research point of view, it is of little practical significance, since stress history parameter should refer to natural soils. Moreover, in case of soil stiffness a key issue is a strain range to which a parameter is referred to. In geotechnical literature, there is no solution accounting for these two aspects with satisfactory level of confidence. The rationale of this paper is to present an approach to description of soil stiffness accounting for stress history and strain range as well. 
ADEQACY OF YOUNG'S

MODULUS IN SOIL STIFFNESS DECRIPTION

\section{Strain range}

In spite of the fact that cohesive soils response to loading rarely (if at all) can be considered elastic, it is known that in a certain range of strain soils reveal true elastic behaviour. It should be emphasized that term "elastic" is ambiguous for such nonlinear behaviour as it is in case of soil. Early works by Hardin and Black (1968) concerning response of soil to dynamic loading showed very small hysteresis loop under cyclic loading in a strain range not exceeding $0.01 \%$. On the other hand, in monotonic tests, a strain range in which elastic behavior is observed is smaller and is upper limit is usually described as $0.001 \%$ (e.g. Jardine et al. 1984). If these ranges of elastic behaviour were to be respected, then models describing the soil response would have to be very complex. However, if the elastic strain limit was shifted in direction of larger strain then soil behaviour would be described as hypoelastic and Young's module would take secant values and strains are not recoverable in a full range. Such approach is practically very convenient and its example of theoretical adequacy is CamClay Model in which inside a yielding surface a material is considered elastic. Such a simplified assumption appears to be very attractive with respect to practical applications since for tunnels, foundations and walls, working strain range refers to $5 \cdot 10^{-3} \div 5 \cdot 10^{-10}$ (Mair 1993). Taking the above into consideration it is stated that use of Young's modulus for soil stiffness description is absolutely justified, although is must be kept in mind that range of strain should be always accounted for.

\section{Stress components and stress history}

Analysis of Young's modulus variability should account for all factors contributing to its value. Besides the above described importance of strain range, one must not disregard another two factors which are stress history and stress level. Certainly, both values refer to effective stress state. It is worth to notice that stress level and stress history are in a way coupled and therefore in order to account for both values, stiffness parameter has to be normalized with respect to one of them. Such approach has been used in soil mechanics for many years. The most eminent example are: Critical State Soil Mechanics born in Cambridge in late 1950s and 1960s and SHANSEP procedure (1974) which originated from MIT. In both cases a soil parameter was normalized with respect to effective stress. This approach has been proved to be useful not only by its simplicity but also it contributed to better understanding of soil behaviour under loading. It allows to separate increase in soil stiffness resulting from stress history from that which results from stress increase. This is very important for description of soil stiffness change.

\section{YOUNG'S MODULUS \\ DISTRIBUTION}

\section{Reconstituted soils of known stress history}

The first step in description of Young's modulus distribution consisted in carrying 
out series of tests on soils with known history. In order to do this it was necessary to prepare slurry material from soil which previously was tested in its natural state. Basic index properties of reconstituted and natural material are presented in Table 1. In order to obtain reconstituted specimens the natural material was kneaded and triturated and then water was added to it with amount necessary to achieve water content around $150 \%$ of liquid limit. Next, the soil had been mixing up to the state when it was a uniform slurry.

Then it was placed in a large cylinder and loaded vertically with weights corresponding to $20 \mathrm{kPa}$ of vertical stress. The cylinder was entirely immersed in water. Boundary conditions with respect to stress components, strain confinement and drainage conditions were analogous to oedometer test. When consolidation was terminated, which was visualized by zero increase of vertical deformation, the cylinder was taken out from water and soil was pushed from it out. Then cylindrical sample was trimmed from consolidated material. Next, a specimen was placed in the triaxial apparatus, and underwent back pressure procedure of saturation. When a specimen was fully saturated, was indicated by Skempton's B parameter value close to 1 , a stage of consolidation commenced. In order to obtain soil of various stress history, each specimen was preconsolidated mechanically to predetermined value of isotropic stress. As a reference stress, at which the soil was sheared, value of $80 \mathrm{kPa}$ was settled. In order to obtained mechanically preconsolidated specimen a specimen was first consolidated to e.g $400 \mathrm{kPa}$ of effective stress. Then, when consolidation was terminated, what was visualized by zero increase in volumetric and axial strain, the specimen was unloaded to reference stress $80 \mathrm{kPa}$ and allowed to deconsolidate. Thus, when the pro-

TABLE 1. Index properties for tested materials

\begin{tabular}{|c|c|c|c|c|c|c|c|}
\hline \multicolumn{8}{|c|}{ UNDISTURBED (NATURAL) SAMPLES } \\
\hline $\begin{array}{l}\text { sampling } \\
\text { depth }\end{array}$ & $\begin{array}{l}\text { clay } \\
\text { friction }\end{array}$ & $\begin{array}{c}\text { water } \\
\text { content }\end{array}$ & $\begin{array}{c}\text { liquid } \\
\text { limit }\end{array}$ & $\begin{array}{c}\text { plastic } \\
\text { limit }\end{array}$ & $\begin{array}{c}\text { index } \\
\text { of plasticity }\end{array}$ & $\begin{array}{l}\text { consistency } \\
\text { index }\end{array}$ & p' \\
\hline$[\mathrm{m}]$ & {$[\%]$} & {$[\%]$} & {$[\%]$} & {$[\%]$} & {$[\%]$} & {$[-]$} & {$[\mathrm{kPa}]$} \\
\hline $6.0-6.6$ & 19 & 14.2 & 22.4 & 11.7 & 10.7 & 0.77 & $\begin{array}{l}100 \\
200 \\
400\end{array}$ \\
\hline $3.5-4.0$ & 13 & 12.6 & 19.7 & 9.8 & 9.9 & 0.72 & $\begin{array}{c}80 \\
200 \\
400\end{array}$ \\
\hline $8.0-8.5$ & 19 & 11.8 & 21.5 & 9.5 & 12 & 0.81 & $\begin{array}{c}80 \\
200 \\
400 \\
\end{array}$ \\
\hline \multicolumn{8}{|c|}{ RECONSTITUTED MATERIAL - INITIAL STATE } \\
\hline OCR & $\begin{array}{c}\text { clay } \\
\text { friction }\end{array}$ & $\begin{array}{c}\text { water } \\
\text { content }\end{array}$ & $\begin{array}{c}\text { liquid } \\
\text { limit }\end{array}$ & $\begin{array}{c}\text { plastic } \\
\text { limit }\end{array}$ & $\begin{array}{c}\text { index } \\
\text { of plasticity }\end{array}$ & $\begin{array}{l}\text { consistency } \\
\text { index }\end{array}$ & p' \\
\hline$[-]$ & {$[\%]$} & {$[\%]$} & {$[\%]$} & {$[\%]$} & {$[\%]$} & {$[-]$} & {$[\mathrm{kPa}]$} \\
\hline $1 ; 2 ; 3 ; 4 ; 5 ; 8$ & 16 & 20.6 & 21.6 & 10.8 & 10.8 & 0.09 & 80 \\
\hline
\end{tabular}


cess of deformation (caused by unloading) stopped, there was a soil specimen in apparatus which was mechanically preconsolidated to known value of overconsolidation ratio $\mathrm{OCR}=5$. Following this procedure specimens were consolidated to the following isotropic effective stresses:

$$
\begin{array}{ll}
\text { OCR }=1 & \sigma_{\mathrm{v}}^{\prime}=80 \mathrm{kPa} \\
\text { OCR }=2 & \sigma_{\mathrm{v}}^{\prime}=160 \mathrm{kPa} \\
\text { OCR }=3 & \sigma_{\mathrm{v}}^{\prime}=240 \mathrm{kPa} \\
\text { OCR }=4 & \sigma_{\mathrm{v}}^{\prime}=320 \mathrm{kPa} \\
\text { OCR }=5 & \sigma_{\mathrm{v}}^{\prime}=400 \mathrm{kPa} \\
\text { OCR }=8 & \sigma_{\mathrm{v}}^{\prime}=640 \mathrm{kPa}
\end{array}
$$

Having prepared specimens for shearing according to the above described procedure the soil specimens were sheared in undrained conditions at rate $0.03 \mathrm{~mm} / \mathrm{min}$. It is worth to emphasize that values of Young's modulus obtained on the basis of the shearing stage refer to undrained conditions.

In order to obtain relationship between stiffness and stress history for reconsti- tuted material the data from shearing were shown in Figure 1 as normalized Young's modulus against OCR.

For each specimen, value of Young's modulus was determined at the following six strain levels expressed in \%:

$$
0.01,0.02,0.05,0.1,0.5,1.0
$$

thus one series of tests corresponding to one stress level consists of six points, since there are distinguished six values of OCR. The points for one stress level can be approximated by regression in the form of power function:

$$
\left(\frac{E}{\sigma^{\prime}}\right)_{K O C}=\left(\frac{E}{\sigma^{\prime}}\right)_{N C} \cdot O C R^{n_{r}}
$$

where:

index NC means that a soil is normally consolidated while index KOC stands for known overconsolidation.

$$
\begin{aligned}
& \left(\frac{E}{\sigma^{\prime}}\right)_{K O C} \begin{array}{l}
\text { lus for mechanically overcon- } \\
\text { solidated soil (known value of } \\
\text { OCR), }
\end{array} \\
&
\end{aligned}
$$

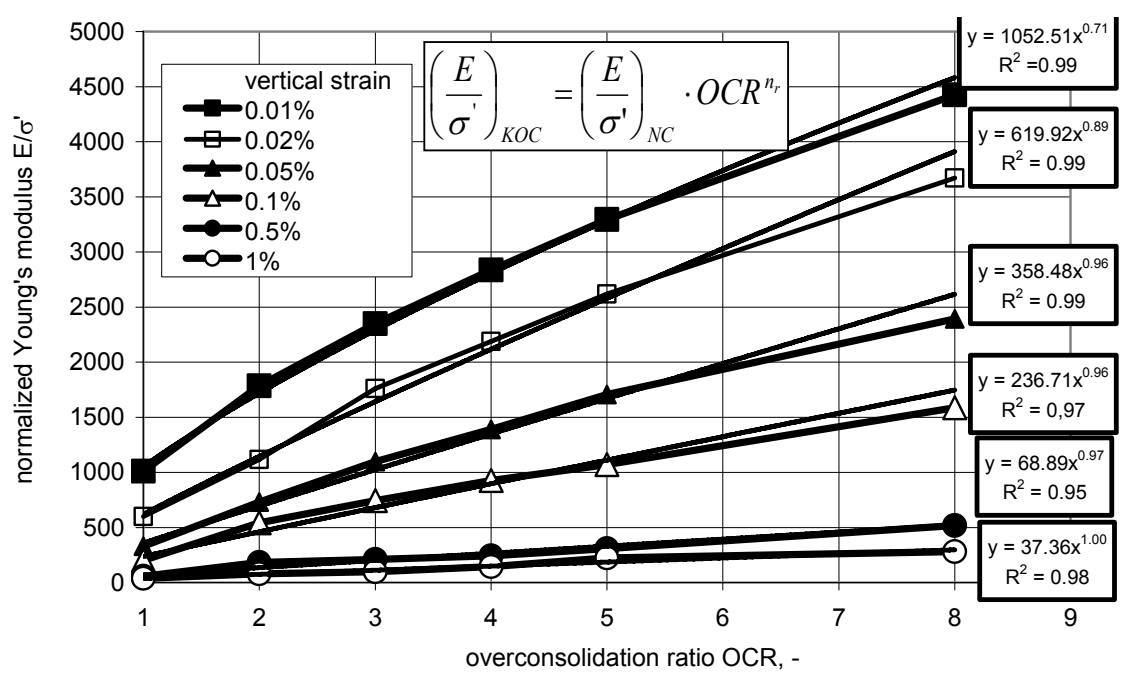

FIGURE 1. Normalized Young's modulus against OCR of reconstituted sandy clays 
$\left(\frac{E}{\sigma^{\prime}}\right)_{N C} \begin{aligned} & - \text { normalized Young's modu- } \\ & \text { lus for normally consolidated } \\ & \text { soil, }\end{aligned}$

OCR - overconsolidation ratio,

$\mathrm{n}_{\mathrm{r}} \quad-$ empirical fitting parameter for reconstituted soil.

For the above specified strain level the relevant formulae are the following:

$$
\begin{aligned}
& \varepsilon_{0.01 \%}\left(\frac{E}{\sigma^{\prime}}\right)_{K O C}=\left(\frac{E}{\sigma^{\prime}}\right)_{N C} \cdot O C R^{0.71} \\
& \varepsilon_{0.02 \%}\left(\frac{E}{\sigma^{\prime}}\right)_{K O C}=\left(\frac{E}{\sigma^{\prime}}\right)_{N C} \cdot O C R^{0.89} \\
& \varepsilon_{0.05 \%}\left(\frac{E}{\sigma^{\prime}}\right)_{K O C}=\left(\frac{E}{\sigma^{\prime}}\right)_{N C} \cdot O C R^{0.96} \\
& \varepsilon_{0.1 \%}\left(\frac{E}{\sigma^{\prime}}\right)_{K O C}=\left(\frac{E}{\sigma^{\prime}}\right)_{N C} \cdot O C R^{0.96} \\
& \varepsilon_{0.5 \%}\left(\frac{E}{\sigma^{\prime}}\right)_{K O C}=\left(\frac{E}{\sigma^{\prime}}\right)_{N C} \cdot O C R^{0.97} \\
& \varepsilon_{1.0 \%}\left(\frac{E}{\sigma^{\prime}}\right)_{K O C}=\left(\frac{E}{\sigma^{\prime}}\right)_{N C} \cdot O C R^{0.99}
\end{aligned}
$$

The chart in Figure 1 clearly indicates that influence of stress history on normalized Young's modulus is coupled with strain level to which this modulus is referred to. If one accounts for definition of overconsolidation ratio then equation (1) can be rewritten in the following form:

$$
\left(\frac{E}{\sigma^{\prime}}\right)_{K O C}=\left(\frac{E}{\sigma^{\prime}}\right)_{N C} \cdot \sigma_{v}^{\prime-n_{r}} \cdot \sigma_{p}^{\prime n_{r}}
$$

This formula clearly shows to what extent various factors contribute to stiff- ness of soil. Another advantage of the formula is a verification of value of normalized Young's modulus for normally consolidated soil. This verification comes from the fact that every test for various OCR value is independent from the others. The analysis of chart shown in Figure 1 proves that extrapolation of regressions of points for each specified strain level for all oveconsolidated specimens confirms normalized modulus value for $\mathrm{NC}$ soil. This enhanced reliability of normalized modulus for NC soil is of great importance since its value is crucial for formulation of analogous description for natural soils.

\section{Natural soils of known stress history}

The principal premise for description of stiffness in natural soil was an analogy to formula of mechanically overconsolidated soil. The major difference between these soils consists in change of preconsolidation stress $\sigma_{p}^{\prime}$ to yielding stress $\sigma_{y}^{\prime}$ and exchange of empirical fitting parameter for reconstituted soil $\mathrm{n}_{\mathrm{r}}$ to its equivalent $\mathrm{n}_{\mathrm{n}}$ for natural soil. This analogy results also in a certain consequence which rests in a fact that when effective vertical stress $\sigma_{v}^{\prime}$ reaches value of yielding stress $\sigma_{y}^{\prime}$ then normalized Young's modulus equals to respective value obtained for reconstituted material with no stress history (NC soil). It is worth to notice that this assumption includes the difference between preconsolidation stress $\sigma_{p}^{\prime}$ and yielding stress $\sigma_{y}^{\prime}$. Since this issue has not been commonly enlightened among geotechnical engineers so far it is worth to explain at least some background of the situation.

Many difficulties in application of standard oedometer procedures of deter- 
mination of stress history in soils created much interest in phenomena which might contribute to the actual value of preconsolidation stress. As indicated by Jamiolkowski et al. (1985), a value of preconsolidation stress resulting from mechanical overburden, can be changed by many postdepositional processes like secondary compressibility, cementation, aging, temperature change and others. Many problems with quantitative description of preconsolidation phenomenon created premises for making a certain order in nomenclature. Burland (1990) proposed that the term "preconsolidation pressure" should be reserved for situations in which the magnitude of such a pressure can be established by geological means. Similarly, the term "overconsolidation ratio" should be reserved for describing mechanically induced, usually known stress history. In case of natural soils, where we do not know cumulative effect of mechanical prestress and other postdepositional phenomena the relevant term for stress corresponding to breakdown in a stress strain curve is "yielding stress". In this case the ratio between it and the effective overburden stress $\left(\sigma_{\mathrm{y}}^{\prime} / \sigma_{\mathrm{vo}}^{\prime}\right)$ could be termed "yield stress ratio". The last terms are typical for cohesive natural soils. In spite of the fact that Burland's proposition introduced a certain semantic order in nomenclature, a reliability of identification of yielding stress in natural soils have not changed. It should be emphasized here that any laboratory procedure based on oedometer tests does not provide a realistic value of yielding stress especially in heavy preconsolidated soils. In such situation there is an evident need to work out an alternative method which would not have all drawbacks inherently associated with oedometer tests and which would be capable to determine effectively the actual yielding stress. Such the alternative method has been worked out by authors. A new approach is based on triaxial test which is much more modern and versatile than oedometer test. The new concept is based on dilatancy phenomenon which takes place during shearing of dense soil. The new method has been described by Wdowska (2010). It is important to emphasize that yielding stress is not preconsolidation stress and new method is capable to determine yielding stress. Therefore in relation to determination of soil stiffness of natural soils if normalized Young's modulus achieves value of normalized stiffness for normally consolidated soils that means that effective normal stress exceeded value of the yielding stress.

In order to derive formula for stiffness of natural soils, three series of tests (3 tests in one series, together 9 tests) have been carried out on natural soils of similar grain size distribution and position on Casagrande chart as reconstituted material. Samples were consolidated at 80,200 and $400 \mathrm{kPa}$, which reflects typical stress range for majority of practical problems. To enhance representativeness of the data, the average of 3 values of modulus determined at one stress level was taken for further analysis. The results of these tests were presented in Figure 2 in the analogous way as for reconstituted material (Fig. 1). However, since data concerns natural soils, on horizontal axis of the chart is vertical effective stress instead of OCR as for reconstituted material. Similarly, as for reconstituted material, normalized Young's modulus was presented 


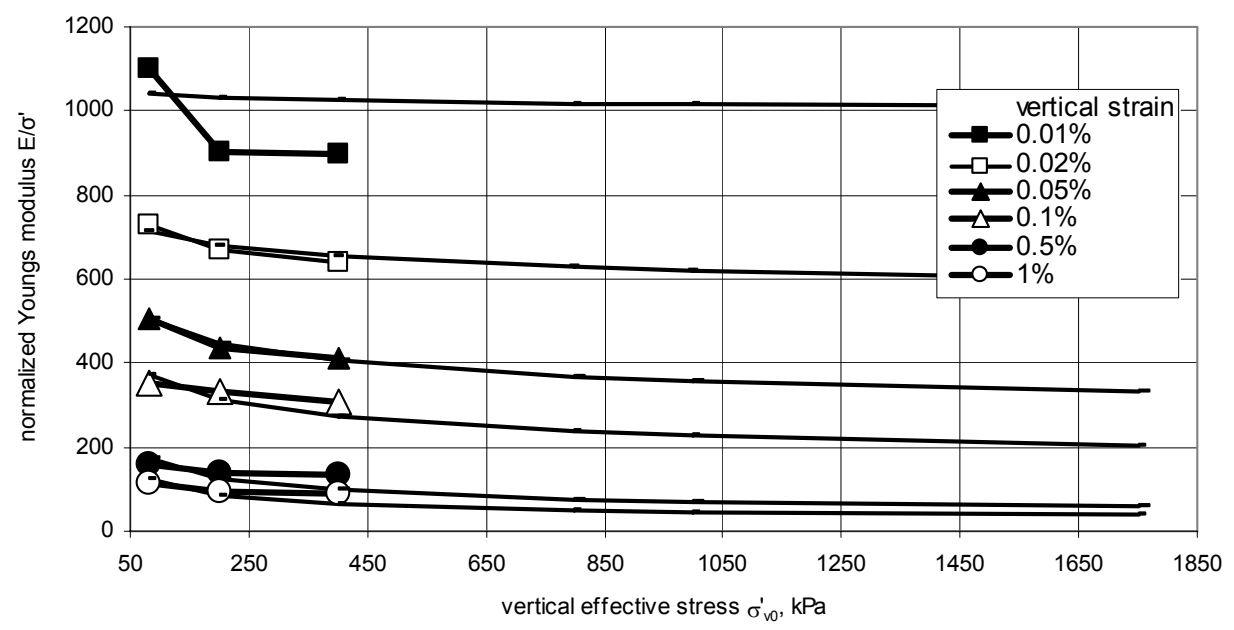

FIGURE 2. Normalized Young's modulus against vertical effective stress for undisturbed sandy clays

for six strain levels. Curves on the charts were created in such way that besides three points for natural the fourth point represents normalized Young's modulus for effective stress equal to yielding stress. Taking advantage of the equation 8 , the data were fitted with curves which describe distribution of normalized Young's modulus for natural sandy clays. The equation for six strain levels are the following:

$$
\begin{aligned}
& \varepsilon_{0.01 \%}\left(\frac{E}{\sigma^{\prime}}\right)_{O C}=\left(\frac{E}{\sigma^{\prime}}\right)_{N C} \cdot \sigma_{v}^{\prime-0.01} \cdot \sigma_{Y}^{\prime 0.01} \\
& \varepsilon_{0.02 \%}\left(\frac{E}{\sigma^{\prime}}\right)_{O C}=\left(\frac{E}{\sigma^{\prime}}\right)_{N C} \cdot \sigma_{v}^{\prime-0.057} \cdot \sigma_{Y}^{\prime 0.057} \\
& \varepsilon_{0.05 \%}\left(\frac{E}{\sigma^{\prime}}\right)_{O C}=\left(\frac{E}{\sigma^{\prime}}\right)_{N C} \cdot \sigma_{v}^{\prime-0.136} \cdot \sigma_{Y}^{\prime 0.136} \\
& \varepsilon_{0.1 \%}\left(\frac{E}{\sigma^{\prime}}\right)_{O C}=\left(\frac{E}{\sigma^{\prime}}\right)_{N C} \cdot \sigma_{v}^{\prime-0.199} \cdot \sigma_{Y}^{\prime 0.199} \\
& \varepsilon_{0.5 \%}\left(\frac{E}{\sigma^{\prime}}\right)_{O C}=\left(\frac{E}{\sigma^{\prime}}\right)_{N C} \cdot \sigma_{v}^{\prime-0.357} \cdot \sigma_{Y}^{\prime 0.357}
\end{aligned}
$$

$\varepsilon_{1.0 \%}\left(\frac{E}{\sigma^{\prime}}\right)_{O C}=\left(\frac{E}{\sigma^{\prime}}\right)_{N C} \cdot \sigma_{v}^{\prime-0.385} \cdot \sigma_{Y}^{\prime 0.385}$

The equations (9)-(14) are different from those for reconstituted material of known stress history. The differences concern empirical fitting parameters $\left(\mathrm{n}_{\mathrm{n}}\right.$ instead $\mathrm{n}_{\mathrm{r}}$ ) and value of preconsolidation stress was substituted by yielding stress. The yielding stress, determined with use of the above mentioned method in triaxial tests was established at level $1750 \mathrm{kPa}$.

As it results from equations 9-14 normalized Young's module depend to large extent on strain levels. It is reflected by value of empirical fitting parameters $n_{n}$, which depend on vertical strain in very nonlinear manner, especially for strain lower than $0.3 \%$. Distribution of empirical fitting parameters for natural soils $n_{n}$ against vertical strain is shown in Figure 3 . These data can be approximated by logarithmic function:

$$
n_{n}=0.08 \ln \varepsilon+0.4
$$




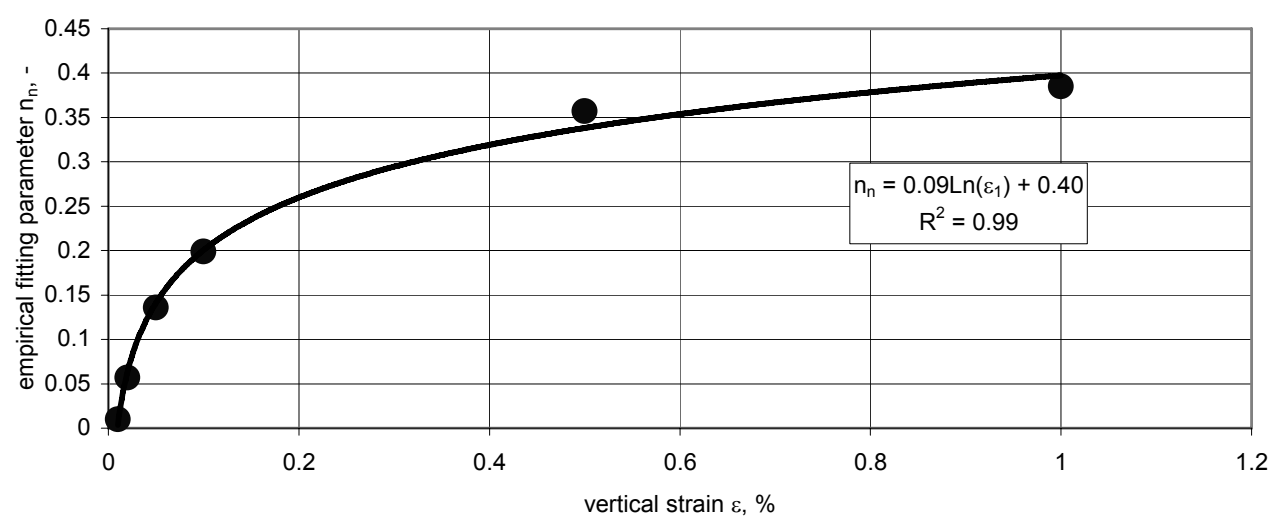

FIGURE 3. Change in empirical fitting parameter against vertical strain for undisturbed sandy clays

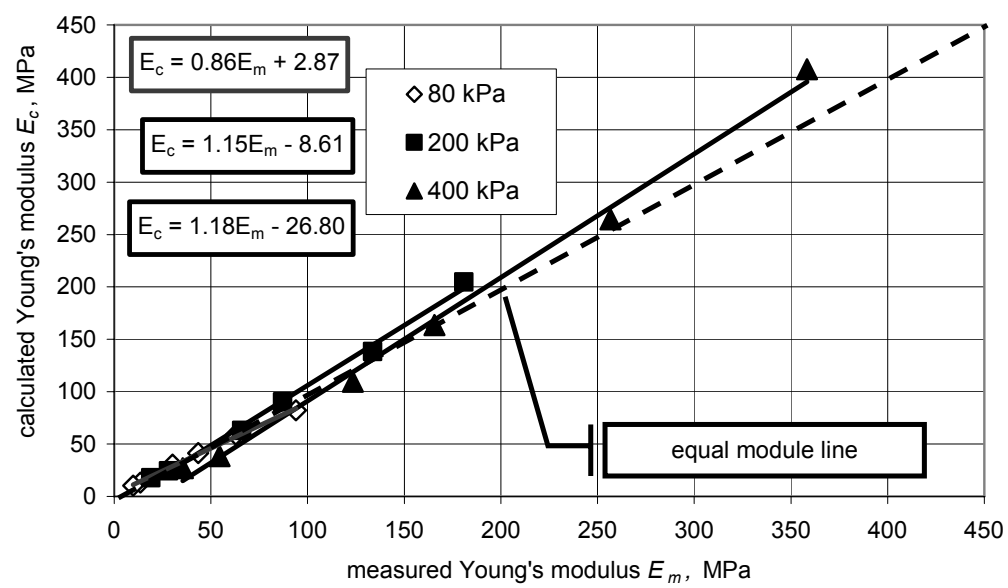

FIGURE 4. Calculated vs. measured Young's modulus for undisturbed sandy clays

Values of strain should be put in percents. It is worth to emphasize that standard deviation of fitting curve is very small, what means that the obtained regression reflects the trend of the data very well.

If equation 15 is combined with equations 9-14 the resulting formula is capable to describe Young's modulus for natural overconsolidated sandy clays in the following form:

$$
(E)_{O C}=\left(\frac{E}{\sigma^{\prime}}\right)_{N C} \cdot \sigma_{v}^{\prime 1-(0.08 \ln \varepsilon+0.4)} \cdot \sigma_{Y}^{\prime}(0.08 \ln \varepsilon+0.4)
$$

The formula (16) takes into account the key variables contributing to Young's modulus value which are:

- vertical effective stress,

- yielding stress,

- vertical strain range. 
In order to verify effectiveness of the above formula it is worth to compare module calculated on the basis the derived formula with measured values of Young's module. The results of such comparison is shown in Figure 4. The chart clearly shows that the derived formula describes stiffness of soil very well, slightly underestimates its for vertical stress lower than $100 \mathrm{kPa}$ and little overestimates its for higher vertical effective stress.

\section{FINAL REMARKS}

The paper concerns fundamental - with respect to serviceability limit state - problem of evaluation of stiffness distribution in heavy overconsolidated clays of moderate plasticity. The objective of the paper was to show that it is possible to derive formula for calculation of Young's modulus, which accounts for all key variables contributing to its actual value. Besides soil kind, they are: stress level, stress history and range of strain to which modulus refers. It is worth to emphasize that stress level and stress history, which are inherently connected, were accounted for with use of normalization technique. Stress history, represented by yielding stress was determined in triaxial tests with use of new method based on dilatancy concept. Nonlinearity of soil stiffness is also accounted for, since one of the variables in the proposed formula is a vertical strain.

\section{REFERENCES}

BURLAND J.B. 1990: On the compressibility and shear strength of natural clays. Géotechnique, Vol. 40(3), 329-378.

HARDIN B.O., BLACK W.L. 1968: Vibration Modulus of Normally Consolidated Clay. Journal of the Soil Mechanics and Foundations Division ASCE. 94 (SM2), 353-369.

JAMIOLKOWSKI M., LADD C.C., GERMAINE J.T., LANCELLOTTA R. 1985: New developments in field and laboratory testing of soils, Proc. 9th Int. Conf. Soil Mech., San Francisco $1,57-153$.

JARDINE R.J., SYMES M.J., BURLAND J.B. 1984: The measurement of soil stiffness in the triaxial apparatus. Géotechnique, Vol. 34 (3), 323-340.

LADD C.C. and FOOTE R. 1974: A New Design Procedure for Stability of Soft Clays. Journal of the Geotechnical Engineering Division, ASCE, Vol. 100, No. GT7, pp. 763-786.

MAIR R.J. 1993: Development in geotechnical engineering research: application to tunnels and deep excavations. Proceedings of the Institution of Civil Engineers, Unwin Memorial Lecture 1992, Civil Engineering, 93, 27-41.

ROSCOE K.H. SCHOFIELD A.N. and WROTH C.P. 1958: On yielding of soils, Geotechnique, 8, 22-53.

SCHOFIELD A.N. and WROTH C.P. 1968: Critical state soil mechanics, London: McGraw-Hill.

WDOWSKA M. 2010: Influence of stress history on evaluation of stiffness of cohesive soils. Ph.D. thesis, WULS -SGGW Warszawa. [In Polish - Wpływ historii naprężenia na odkształcalność gruntów spoistych.].

Streszczenie: Określenie sztywności prekonolidowanych gruntów spoistych uwzględniajace historię stanu naprężenia i zakres odksztatceń. Artykuł dotyczy opisu sztywności średnio spoistego gruntu silnie prekonsolidowanego. Materiał doświadczalny obejmuje badania trójosiowe na próbkach gruntu naturalnego o nienaruszonej strukturze (9 badań) i na próbkach rekonstruowanych ( 6 badań). Próbki rekonstruowane były obciążane, doprowadzane do końca konsolidacji, a następnie odciążane. $\mathrm{W}$ ten sposób otrzymano grunt prekonsolidowany mechanicznie o znanym zakresie OCR od 1 do 8 . Próbki rekonstruowane o nienaruszonej strukturze były ścinane w warunkach bez odpływu, a zatem wielkości modułu odkształcenia E należy odnosić do tych warunków. Przeprowadzone badania pozwoliły na ustalenie formuł opisujących zmiany wartości modułu w zależności od podstawowych wielkości mających wpływ na ostateczną jego wartość, tj. wielkość zadawanych naprężeń efek- 
tywnych, naprężenie prekonsolidacji $\sigma_{\mathrm{p}}^{\prime}$ dla gruntów rekonstruowanych, naprężenia uplastycznienia $\sigma_{y}^{\prime}$ dla gruntów nienaruszonych (w stanie naturalnym), a także wartość odkształcenia pionowego do którego odnosi się wielkość sztywności. Należy podkreślić, że wartość naprężenia uplastycznienia $\sigma_{y}^{\prime}=1750 \mathrm{kPa}$ została określona przy wykorzystaniu nowej metody opartej na zjawisku dylatancji gruntu, natomiast wartości odkształceń, do którego można zastosować proponowaną formułę obejmują szeroki zakres $0,01 \div 1,00 \%$, wpisujący się $\mathrm{w}$ najbardziej istotny przedział $\mathrm{z}$ punktu widzenia praktyki inżynierskiej.

Stowa kluczowe: silnie prekonsolidowana glina piaszczysta, znormalizowany moduł odkształce- nia, historia stanu naprężenia, zakres odkształceń, aparat trójosiowy.

MS. received November 2011

\section{Authors' address:}

Mirosław J. Lipiński, Małgorzata Wdowska

Katedra Geoinżynierii

Szkoła Główna Gospodarstwa Wiejskiego

ul. Nowoursynowska 159

02-776 Warszawa

Poland

e-mail: miroslaw_lipinski@sggw.pl

malgorzata_wdowska@sggw.pl 